\title{
Relational Analysis of Farmer's Profile with their Perception about Climate Change in Marathwada Region, India
}

\author{
S.D. Mundhe*, D.D. Suradkar, J.M. Deshmukh and V.G. Dhulgand \\ Department of Extension Education College of Agriculture, Latur, Vasantrao Naik \\ Marathwada Krishi Vidyapeeth, Parbhani-431402 (M.S.) India \\ *Corresponding author
}

\begin{tabular}{|l|}
\hline Ke y w or d s \\
Climate change, \\
$\begin{array}{l}\text { Relationship } \\
\text { between profile and } \\
\text { perception }\end{array}$ \\
\hline Article Info \\
\hline $\begin{array}{l}\text { Accepted: } \\
\text { 20 May } 2019 \\
\text { Available Online: } \\
\text { 10 June 2019 }\end{array}$ \\
\hline \hline
\end{tabular}

\section{A B S T R A C T}

The present study was conducted mainly with the objective to study "Farmer's perception about climate change in Marathwada Region." For the study, Latur and Beed district were selected from Marathwada region of Maharashtra state during the years 2018-19. Four talukas viz., Latur and Renapur of Latur District and Kaij and Ambajogai from Beed district were selected randomly and two villages from each talukas were selected randomly. From each village fifteen members were randomly selected constituting the sample size 120. Ex-post-facto research design was used for the study. A number of profile characteristics were selected as independent variables to find out profile of farmers of the study area. It was found that, majority $(39.17 \%)$ of respondents educated up to middle school, (57.50\%) had medium farming experience, 55 per cent medium social participation, 76.67 per cent having farming as their major occupation, 33.33 per cent respondents were marginal farmers, $(66.67 \%)$ reported that well as a main source of irrigation, (79.17\%) medium annual income, $(69.17 \%)$ medium socio-economic status, 63.33 per cent had medium awareness about crop insurance, (66.67\%) medium extension contact, $60.00 \%$ medium innovativeness category and $(55.00 \%)$ medium risk orientation. Findings showed that farmers have fairly high level of perception about climate change and its various dimensions. The results regarding perception of farmer's about climate change shows that, 54.17 per cent of farmers had medium perception, 27.50 per cent farmers had high perception about climate change followed by 18.33 per cent of farmers had low perception level about climate change. It was observed that, independent variable like education, annual income, socio-economic status, crop insurance, risk orientation found positive and highly significant relationship with perception of farmers about climate change and farming experience, social participation, occupation, land holding, irrigation facilities, extension contact and innovations found positive significant relationship with perception.

\section{Introduction}

The Marathwada region of Maharashtra is just coming out of the worse drought in forty years. While the drought of the magnitude in 2016 will always bring hardship to local people which causes the effects of extreme weather on local livelihood. The district of 
Marathwada witnessing maximum farmers suicides in Maharashtra face higher risk to climate change. According to the Central Research Institute for Dry land Farming, the districts in Marthwada face very high risk to climate change. Climate change and agriculture have a very strong linkage. Agriculture still depends fundamentally on the weather. Climate change is already responsible for the decrease in the agricultural productivity because of the severely changing weather patterns. Climate change is responsible for continuous occurrences of floods, worsening desertification process and disrupts growing season. Climate change can affect agricultural productivity in many ways. Agriculture places heavy burden on the environment in the process of providing humanity with food and fibre, while climate is the primary determinant of agricultural productivity. Given the fundamental role of agriculture in human welfare, concern has been expressed by federal agencies and others regarding the potential effects of climate change on agricultural productivity. Interest in this issue has motivated a substantial body of research on climate change and agriculture over the past decade.

The main objectives include studying the profiles of farmers. And also to study relationship between perception of farmers about climate change and profile of farmers.

\section{Materials and Methods}

The present study was conducted in Latur and Beed district of Marathwada region from Maharashtra state. In Latur district there are ten tahsils, out of which two tahsils namely Latur, Renapur were randomly selected and change in Beed district there are 11 tahsils out of which two tahsils namely Ambajogai and Kaij on the basis "Farmer's perception about climate change in Marathwada Region" From each tahsils two villages were randomly selected and from each village fifteen farmers were randomly selected to comprise 120 respondents. Ex-post facto research design was used for the study. Data were collected by personally interviewing the respondents with the help of pretested structural schedule. Collected data were tabulated properly. Mean and standard deviation, frequency, percentage, coefficient of correlation methods of statistics were used for interpretation of data.

\section{Results and Discussion}

\section{Personal and socio-economic characteristics of the respondents}

A number of profile characteristics were selected as independent variables to find out profile of farmers of the study area. It was observed from Table 1 that, majority of $(39.17 \%)$ respondents belongs to middle school category followed by, 20.84 per cent respondents were found in high school category, 18.33 per cent respondents belongs to College/ Post graduation, 10.00 per cent respondents had education level up to primary school, 9.16 per cent respondents were found under illiterate category, 2.50 per cent of the respondents were found that they can read and write category and none of this belongs to under can read only category. Farming experience wise composition of the study sample reveals that, majority of the respondents $(57.50 \%)$ had 'medium' farming experience category while 22.50 per cent respondents belongs to low farming experience category and 20.00 per cent of respondents were found to be having 'high' level of farming experience. As regards social participation majority $(55.00 \%)$ of the respondents had medium category of social participation, while 24.16 per cent respondents had high social participation and 20.84 per cent of them were found in low social participation category. As regard to 
occupation, majority of respondents $(76.67 \%)$ of them were engaged in farming alone. Nearly 8.33 per cent of the respondents were practicing agriculture along with service as their main occupation whereas, 6.67 per cent were engaged in agriculture along with caste occupation followed by about 5.00 per cent of them were doing agriculture along with labour and 3.33 per cent of them were engaged in agriculture along with business.

Land holding, majority $(39.17 \%)$ of the respondents were possessing 1.01 to 2.00 ha of land and belongs to small farmers category while 33.33 per cent of the respondents were possessing up to 1 ha of land and belongs to marginal farmers category, and 16.67 per cent of the respondents belonged to medium farmers category (2.01 to 4 ha) whereas; 10.00 per cent farmers included under semi medium farmers category (4.01 to $10.00 \mathrm{ha}$ ) category and very meagre 00.83 per cent of the respondents had more than 10 ha land holding which comes under big farmer's category. Majority $(66.67 \%)$ of farmers had well as irrigation source followed by, (26.67\%) had borewell as irrigation facility, near about 3.33 per cent farmers had pond as irrigation facility, 2.50 per cent farmers depend upon the canal as source of irrigation, 0.83 per cent of farmer had farm pond as source of irrigation and nobody depends on both river and dam as source of irrigation. As regards annual income majority of farmers (79.17\%) belongs 'medium' annual income followed by high $(13.33 \%)$ and low $(7.50 \%)$. Majority of the respondents $(69.17 \%)$ reported 'medium' socio-economic status, followed by, $15.83 \%$ 'high' socio-economic status and 15.00\% 'low' socio-economic status. As regards their awareness about crop insurance, $63.33 \%$ had 'medium awareness' followed by $23.34 \%$ having 'high' awareness and $13.33 \%$ farmers had low awareness about crop insurance. Additionally, majority $(66.67 \%)$ of respondents had medium level of extension contact followed by $(19.17 \%)$ and $(14.16 \%)$ high and low extension contact respectively. As regards innovativeness was quite interesting as 60.00 per cent of study area farmers were in the medium innovative proneness category, while, 25.00 and 15.00 per cent of them were in high and low innovativeness categories, respectively. Majority $(55.00 \%)$ of the respondents were having medium level of risk orientation, whereas, 28.33 per cent and 16.67 per cent belongs to high and low category respectively.

\section{Relationship between farmers' profile characteristics and their Perceptions about climate change}

Findings presented in Table 2 reveals that out of fourteen independent variables, education, farming experience, social participation, occupation, land holding, irrigation facilities, annual income, socio-economic status, crop insurance, extension contact, innovativeness, risk orientation were found to be positively related and remaining variable like education, annual income, socioeconomic status, crop insurance, risk orientation found positive and highly significant relationship with perception of farmers about climate change.

Majorities of the respondents were having education up to middle school, medium farming experience. Also clearly observed that majority of farmers had farming was main occupation, farmers belong to small land holding category, had well was main source of irrigation and belongs to medium annual income category, had medium category of socioeconomic status and farmers have better knowledge about the crop insurance. 
Table.1 Distribution of respondents according to their profile $(\mathrm{N}=120)$

\begin{tabular}{|c|c|c|c|}
\hline Sr. No. & Variable & Frequency $(\mathrm{F})$ & Percentage (\%) \\
\hline \multirow[t]{8}{*}{1.} & \multicolumn{3}{|l|}{ Education } \\
\hline & Illiterate & 11 & 9.16 \\
\hline & Can read only & 00 & 00.00 \\
\hline & Can read and write & 03 & 2.50 \\
\hline & Primary school & 12 & 10.00 \\
\hline & Middle school & 47 & 39.17 \\
\hline & High school & 25 & 20.84 \\
\hline & College level & 22 & 18.33 \\
\hline \multirow[t]{4}{*}{2.} & \multicolumn{3}{|l|}{ Farming Experience } \\
\hline & Low & 27 & 22.50 \\
\hline & Medium & 69 & 57.50 \\
\hline & High & 24 & 20.00 \\
\hline \multirow[t]{4}{*}{3.} & \multicolumn{3}{|l|}{ Social Participation } \\
\hline & Low & 25 & 20.84 \\
\hline & Medium & 66 & 55.00 \\
\hline & High & 29 & 24.16 \\
\hline \multirow[t]{6}{*}{4.} & \multicolumn{3}{|l|}{ Occupation } \\
\hline & Labour & 06 & 05.00 \\
\hline & Caste occupation & 08 & 06.67 \\
\hline & Business & 04 & 03.33 \\
\hline & Farming & 92 & 76.67 \\
\hline & Service & 10 & 08.33 \\
\hline \multirow[t]{6}{*}{5.} & \multicolumn{3}{|l|}{ Land Holding } \\
\hline & Marginal & 40 & 33.33 \\
\hline & Small & 47 & 39.17 \\
\hline & Medium & 20 & 16.67 \\
\hline & Semi Medium & 12 & 10.00 \\
\hline & Big & 01 & 00.83 \\
\hline \multirow[t]{8}{*}{6.} & \multicolumn{3}{|l|}{ Irrigation facilities } \\
\hline & River & 00 & 00.00 \\
\hline & Pond & 04 & 03.33 \\
\hline & Well & 80 & 66.67 \\
\hline & Farm pond & 01 & 00.83 \\
\hline & Dam & 00 & 00.00 \\
\hline & Canal & 03 & 02.50 \\
\hline & Bore well & 32 & 26.67 \\
\hline \multirow[t]{2}{*}{7.} & \multicolumn{3}{|l|}{ Annual Income } \\
\hline & Low & 09 & 07.50 \\
\hline
\end{tabular}




\begin{tabular}{|c|c|c|c|}
\hline & Medium & 95 & 79.17 \\
\hline & High & 16 & 13.33 \\
\hline \multirow[t]{4}{*}{8.} & \multicolumn{3}{|c|}{ Socioeconomic Status } \\
\hline & Low & 18 & 15.00 \\
\hline & Medium & 83 & 69.17 \\
\hline & High & 19 & 15.83 \\
\hline \multirow[t]{4}{*}{9.} & \multicolumn{3}{|c|}{ Crop Insurance } \\
\hline & Low & 16 & 13.33 \\
\hline & Medium & 76 & 63.33 \\
\hline & High & 28 & 23.34 \\
\hline \multirow[t]{4}{*}{10.} & \multicolumn{3}{|c|}{ Extension Contact } \\
\hline & Low & 17 & 14.16 \\
\hline & Medium & 80 & 66.67 \\
\hline & High & 23 & 19.17 \\
\hline \multirow[t]{4}{*}{11.} & \multicolumn{3}{|c|}{ Innovativeness } \\
\hline & Low & 18 & 15.00 \\
\hline & Medium & 72 & 60.00 \\
\hline & High & 30 & 25.00 \\
\hline \multirow[t]{4}{*}{12.} & \multicolumn{3}{|c|}{ Risk orientation } \\
\hline & Low & 20 & 16.67 \\
\hline & Medium & 66 & 55.00 \\
\hline & High & 34 & 28.33 \\
\hline
\end{tabular}

Table.2 Coefficient of correlation between profiles of farmers with their perception about climate change

\begin{tabular}{|c|l|c|}
\hline Sr. No. & Independent Variables & Correlation coefficient $(\mathbf{r})$ \\
\hline $\mathbf{1 .}$ & Education & $0.266^{* *}$ \\
\hline $\mathbf{2 .}$ & Farming experience & $0.199^{*}$ \\
\hline $\mathbf{3 .}$ & Social participation & $0.210^{*}$ \\
\hline $\mathbf{4 .}$ & Occupation & $0.213^{*}$ \\
\hline $\mathbf{5 .}$ & Land holding & $0.214^{*}$ \\
\hline $\mathbf{6 .}$ & Irrigation facilities & $0.206^{*}$ \\
\hline $\mathbf{7 .}$ & Annual income & $0.316^{* *}$ \\
\hline $\mathbf{8 .}$ & Socio-economic status & $0.373^{* *}$ \\
\hline $\mathbf{9 .}$ & Crop insurance & $0.329^{* *}$ \\
\hline $\mathbf{1 0 .}$ & Extension Contact & $0.222^{*}$ \\
\hline $\mathbf{1 1 .}$ & Innovativeness & $0.213^{*}$ \\
\hline $\mathbf{1 2 .}$ & Risk orientation & $0.289^{* *}$ \\
\hline
\end{tabular}


Independent variables, education, farming experience, social participation, occupation, land holding, irrigation facilities, annual income, socio-economic status, crop insurance, extension contact, innovativeness, risk orientation, were found to be positively related and remaining variable like education, annual income, socio-economic status, crop insurance, risk orientation found positive and highly significant relationship with perception of farmers about climate change.

\section{References}

Chand, S. and D. Kumar, 2018. Farmers' perception on climate change and its management strategies: A Micro Analysis of Rajasthan. Indian Res. J. Ext. Edu. 18 (3).

Grimberg, B.I., S. Ahmed, C. Ellis, Z. Miller and F. Menalled 2018. Climate Change Perceptions and Observations of Agricultural Stakeholders in the Northern Great Plains, Journal of Sustainability, 10(5), pp. 1687.

Islam, S, M.H. Kabir, S. Ali, S. Sultana, M. Mahasin (2019) Farmers' Knowledge on Climate Change Effects in Agriculture Journal of Agricultural Sciences pp: 386-394.

Onyekuru, N.A. and Marchant, R. 2017. Climate change perception, awareness and adaptation decision among forest communities in Nigeria. Agro-Science, $16(3)$, pp. $51-62$.

Osei, S. 2017. Climate Change Adaptation Constraints among Smallholder Farmers in Rural Households of Central Region of Ghana. West African Journal of Applied Ecology, 25(2), pp. 31-48.

Sivaraj P., H. Philip and V. Geethalakshmi. 2017. Climate Change Impact on SocioEconomic Status and Communication Pattern of the Paddy Farmers of Tamil Nadu, India International Journal of Current Microbiology and Applied Sciences 6 (6) pp. 550-557.

Uddin, M.N., W. Bokelmann, and E.S. Dunn, 2017. Determinants of Farmers Percepti on of Climate Change: A Case Study from the Coastal Region of Bangladesh. American Journal of Climate Change, (6), PP. 151-165.

\section{How to cite this article:}

Mundhe, S.D., D.D. Suradkar, J.M. Deshmukh and Dhulgand, V.G. 2019. Relational Analysis of Farmer's Profile with their Perception about Climate Change in Marathwada Region. Int.J.Curr.Microbiol.App.Sci. 8(06): 2748-2753. doi: https://doi.org/10.20546/ijcmas.2019.806.331 